\title{
Cognitive and functional assessment about elderly people users of health public service ${ }^{a}$
}

\author{
Avaliação cognitiva e funcional de idosos usuários do serviço público de saúde \\ Evaluación funcional y cognitiva de los ancianos usuários de los servicios de salud pública
}

Beatriz Rodrigues de Souza Melo ${ }^{1}$ Maria Angélica Andreotti Diniz ${ }^{1}$ Francine Golghetto Casemiro ${ }^{1}$ Leandro Correa Figueiredo ${ }^{1}$ Ariene Angelini dos Santos-Orlandi ${ }^{1}$ Vanderlei José Haas $^{2}$

Fabiana de Souza Orlandi ${ }^{1}$ Aline Cristina Martins Gratão ${ }^{1}$

1. Universidade Federal de São Carlos.

São Carlos, SP, Brazil.

2. Universidade Federal do Triângulo Mineiro. Uberaba, MG, Brazil
Corresponding author:

Aline Cristina Martins Gratão.

E-mail: aline-gratao@hotmail.com

Submitted on 01/02/2017.

Accepted on 05/09/2017.

DOI: 10.1590/2177-9465-EAN-2016-0388

\section{Abstract}

Objective: To evaluate the functional capacity, cognition and mood in three different care models for older adults. Method: A cross-sectional study conducted in 2014 with 140 older adults (37 institutionalized, 53 hospitalized and 50 outpatients). The MMSE, Clock Drawing Test (CDT), Activities of Daily Living Scale - ADLs (Katz, Lawton) and the Geriatric Depression Scale (GDS) were applied. Results: Of those institutionalized, the majority were totally dependent for ADLs and $100 \%$ presented cognitive decline. Of those hospitalized and the outpatients, the majority were independent for ADLs, with $62.3 \%$ and $48.0 \%$ presenting cognitive decline, respectively. The minority presented depressive symptoms. The results indicated that age was a predictor of cognitive decline and the likelihood of prevalence in hospitalized and outpatient older adults increased by $8.7 \%$ for each year of life. Conclusion: It is important to pay attention to the cognitive and functional performance of older adults with the aim of preventing their decline, which is so frequent in the public health services in Brazil.

Keywords: Older adult; Daily Activities; Cognition.

\section{Resumo}

Objetivo: Avaliar a capacidade funcional, cognitiva e humor em três diferentes modelos de atenção ao idoso. Método: Estudo seccional, comparativo, realizado em 2014 com 140 idosos (37 institucionalizados, 53 hospitalizados e 50 ambulatoriais). Aplicou-se o MEEM, Teste do Desenho do Relógio (TDR), Escala de Atividades de Vida Diária - AVDs (Katz, Lawton) e Escala de Depressão Geriátrica (EDG). Resultados: Dos institucionalizados, a maioria estava totalmente dependente para AVDs e $100 \%$ apresentaram declínio cognitivo. No hospital e ambulatório, maioria independente para AVDs, sendo $62,3 \%$ e $48 \%$ com declínio cognitivo, respectivamente. A minoria apresentou sintomas depressivos. Os resultados indicaram que a idade foi preditor de declínio cognitivo e as chances de prevalência em idosos hospitalizados e ambulatoriais aumentam 8,7\% para cada ano de vida. Conclusão: Destaca-se a importância de se dedicar atenção ao desempenho cognitivo e funcional dos idosos objetivando a prevenção do declínio destes, tão frequentes nos serviços públicos de saúde no Brasil.

Palavras-chave: Idoso; Atividades Cotidianas; Cognição.

\section{Resumen}

Objetivo: Evaluar la capacidad funcional, cognitiva y el estado de ánimo en tres modelos diferentes de la atención a las personas mayores. Método: Estudio transversal comparativo realizado en el año 2014 con 140 ancianos (37 institucionalizados, 53 hospitalizados y 50 ambulatorios). Aplicado el MMSE, test del reloj, Actividades de la Vida Diaria Escala (Katz, Lawton) y Escala de Depresión Geriátrica. Resultados: El institucionalizada, la mayoría totalmente dependiente para ADL y el 100\% tenían deterioro cognitivo. En hospitales y clínicas, muchos independiente para ADL, con el $62,3 \%$ y el $48 \%$ con el deterioro cognitivo, respectivamente, la minoría tenía síntomas depresivos. Los resultados indicaron que la edad es un predictor de deterioro cognitivo y las posibilidades de prevalencia en hospitalizados y ambulatorios ancianos aumento del 8,7\% por cada año de vida. Conclusión: Cabe destacar la importancia de dar atención al rendimiento cognitivo y funcional de las personas mayores a la prevención disminución de éstos, tan frecuentes en los servicios de salud pública en Brasil.

Palabras clave: Anciano; Actividades Cotidianas; Cognición. 


\section{INTRODUCTION}

For decades, population aging has been a reality for both developed and developing countries. ${ }^{1}$ In Brazil, reducing fertility rates have resulted in declining population growth, and declining infant and child mortality rates. The increase in life expectancy has also favored the increase in the population contingent of older adults. ${ }^{2}$

The Brazilian age group pyramid has, for many years, evidenced the ascendancy of children and young people, showing a broad base and narrow top. Currently, it shows characteristics of balance between the age groups, with a tendency for the enlargement of the top. Concomitantly with the demographic transition, there is a change in the epidemiological landscape. ${ }^{3}$ In this sense, it is important to highlight the high prevalence of chronic noncommunicable diseases, cognitive losses, sensorial decline and social isolation. These factors may cause deterioration in the functional capacity of older adults, making them dependent on other people for their daily care. ${ }^{4}$

Functional dependence can be defined as the inability to maintain the physical and mental skills necessary for independent and autonomous living. Persons affected by incapacitating processes may suffer limitations in the performance of activities related to self-care - Basic Activities of Daily Living (BADLs) and in the performance of activities related to the organization of the daily routine - Instrumental Activities of Daily Living (IADLs). ${ }^{5}$

As provided by law, health actions directed toward older adults aim for the maximum maintenance of autonomy and independence, however, there are factors that configure complications to achieve these goals. Among these factors, cognitive decline is given more emphasis. ${ }^{6}$

Cognitive decline consists of a slight slowing of mental abilities that evolves with advancing age and may be associated with various factors, such as: dementia, medication use (mainly benzodiazepines, neuroleptics and antidepressants) and mood alterations, particularly depression, among others. ${ }^{7}$

In view of the above, it is essential to evaluate the cognitive and functional capacity of older adults. Through a broad geriatric evaluation, these aspects will be addressed by health professionals, who will be able to identify the demands of each older adult evaluated and establish an individualized care plan that promotes active aging and improves quality of life. An in-depth evaluation provides subsidies for health decision-making and for the design of strategic actions aimed at the particularities of each older adult, in order to provide them with integral health care, as recommended by the National Policy for Older Adult Health. ${ }^{8}$

One of the aspects highlighted by this Policy is the promotion of active and healthy aging, which can be accomplished through the optimization of health, participation and safety opportunities, with the aim of improving the quality of life as people age. One of the aspects addressed in active aging is good functional capacity. ${ }^{9}$
Support for the older adult population still represents a challenge for the Brazilian Health System, especially regarding the knowledge of the health needs of this population. This context seems to have allowed an increase of specialists in different areas of professional activity, interested in developing actions related to the older adult public and, in the health area, focusing on the preservation of the functional and cognitive capacity.

Thus, studies that address this issue are essential to support the health policies aimed at older adults. Although the current literature indicates the multiple characteristics of older adults in institutional, hospital and outpatient settings, there is still a need to further explore knowledge, considering that these characteristics may vary according to the specificities of each context. Thus, the present study aimed to evaluate the functional capacity, cognition and mood of the older adults of three different older adult care models in São Carlos - SP, favoring the implementation and improvement of the planning of integrated health actions for these people.

\section{METHODS}

This was an observational, cross-sectional, comparative, quantitative study to verify the sociodemographic and health profile and the functional and cognitive capacity of the older adults of the municipality of São Carlos-SP.

The target population consisted of older adults, aged 60 years or older, that were users of three different types of public healthcare in the municipality of São Carlos. They were studied simultaneously in three groups. The first included older adults undergoing medical care at the University Health Unit (UHU) of the Federal University of São Carlos/UFSCar, considered a medium complexity outpatient clinic that attends users referred by the public health network of São Carlos and region. The second group consisted of older adults treated at the University Hospital (UH) of the Federal University of São Carlos/UFSCar, which is integrated into the Network (Primary and Secondary Care Units) offering healthcare, and provides observation/hospitalization services and emergency care for the population. The third group was represented by older adults from the Cantinho Fraterno Dona Maria Jacinta Long-Stay Institution for Older Adults (LSIOA), this being a philanthropic institution, located in the urban environment of the city of São Carlos, founded in 1922. At the time of the study it was home to approximately 37 elderly people.

The total sample consisted of 140 older adults (37 institutionalized, 53 hospitalized and 50 outpatients) and the analysis of the sample power, using the Power Analysis and Sample Size (PASS) application, 2002, for a significance level of $A=0.05$ and a sample size of $n=140$, revealed an a priori statistical power of $1-\beta=99.8 \%$.

Data collection was performed in the first half of 2014 and only started after approval from the Research Ethics Committee 
of the Federal University of São Carlos. Individual interviews were conducted, with the consent of the study participants, who all signed the consent form.

For the characterization of the older adults, an instrument was applied that included the following information: gender, age group, education level, marital status, nationality, place of origin, with whom they live, self-reported diseases and life habits.

Cognitive performance was evaluated through the Mini Mental State Examination (MMSE). This instrument was translated and validated for Brazil by Bertolucci ${ }^{10}$ and tracks possible cognitive deficits in individuals at risk of developing dementia syndrome. The score can range from 0 to 30 points. The cut-off score was calculated with the median values presented by age group and a standard deviation subtracted. ${ }^{7}$ The cut-off points adopted were: 18 points for illiterate people; 21 points for those with one to three years of schooling; 24 points for four to seven years of schooling and 26 points for eight years of schooling or more.

The Clock Drawing Test (CDT) is a cognitive evaluation tool validated in Brazil, ${ }^{11}$ which consists of a scoring scale of 0 (totally incorrect or non-existent clock) to 10 points (fully correct clock).

The depressive symptomatology was evaluated using the 15-item version of the Geriatric Depression Scale (GDS), validated in Brazil by Almeida and Almeida. ${ }^{12}$ A score of 5 points indicates absence of depressive symptoms, 6 to 10 points: mild depressive symptoms and 11 to 15 points: severe depressive symptoms.

Limitations in the Basic Activities of Daily Living (BADLs) were assessed using the Katz Index of Independence in Activities of Daily Living. This instrument investigates self-care activities, such as: bathing, dressing, going to the bathroom, lying down and getting out of bed, eating and controlling urination and/or evacuation functions. This scale was adapted for use in Brazil by Lino et al. ${ }^{13}$ Shelkey and Wallace ${ }^{14}$ proposed a point for each activity that the evaluated person does without help. This score varies from 0 to 6 points, with individuals that obtain from 0 to 2 points being considered totally dependent, 3 to 5 points partially dependent and individuals that obtain 6 points considered independent.

Limitations in the Instrumental Activities of Daily Life (IADLs) were evaluated through the Lawton and Brody Instrumental Activities of Daily Living Scale, adapted to the Brazilian context by Santos and Virtuoso Junior in 2008. ${ }^{15}$ Examples of IADLs are: using the telephone, using some means of transportation, shopping, preparing meals, cleaning and tidying up the house, taking medications and dealing with finances. The score varies from 7 to 21 points, with a score of 7 points being considered total dependence, 8 to 20 points partial dependence and 21 points independence.

Descriptive and univariate data analysis was performed using the Statistical Package for the Social Science (SPSS), version 20.0, program, for both the categorical variables (frequency tables) and the quantitative variables (measures of central tendency and variability). Pearson's correlation calculation was also performed between the quantitative variables. The correlations were considered weak $(r<0.3)$, moderate $(0.3 \leq r<0.7)$ or strong $(r \geq 0.7)$. The midpoints of the functional capacity measures (Katz Index of Independence in Activities of Daily Living and Lawton and Brody Instrumental Activities of Daily Living Scale) were statistically analyzed through the non-parametric Mann-Whitney test with Bonferroni correction. In order to adjust the prevalence ratios of cognitive decline to the institutions, according to the variables gender, age, presence of depressive symptoms and morbidities, a multiple logistic regression model was constructed with the simultaneous input of predictors, or saturated model, method. The level of significance was $a=0.05$.

All the ethical guidelines that govern research with human subjects were observed and respected, according to Resolution 466/2012, regulated by the National Health Council. This study was approved by the Research Ethics Committee of the Federal University of São Carlos, under authorization number 416.459, on 10/6/2013, CAAE 21522513.8.0000.5504.

\section{RESULTS}

A total of 140 older adults were interviewed, 37 of whom were evaluated in the LSIOA, 53 in the $\mathrm{UH}$ and 50 in the UHU. The sociodemographic and health characteristics of the older adults were presented considering the three care modalities and the main differences related to the items: to have or not cognitive decline, functional capacity and the presence or not of depressive symptoms.

Table 1 shows the distribution of the older adults in the three care modes according to gender, marital status, health profile, mood and cognition.

In the LSIOA, there was predominance of males (54.1\%), single $(67.6 \%)$, non-smokers $(83.8 \%)$, that did not practice physical activities $(86.5 \%)$, did not have depressive symptoms $70.3 \%$ ) and presented cognitive decline (100.0\%). Hypertension was reported by $32.4 \%$ of the participants and diabetes mellitus by $18.9 \%$.

In the $\mathrm{UH}$, the older adults were mostly married (56.6\%), non-smokers (77.4\%), did not practice physical activities $(62.3 \%)$, did not have depressive symptoms (58.5\%) and presented cognitive decline (62.3\%). Regarding the diseases reported, $41.5 \%$ were hypertensive and $26.4 \%$ said they had diabetes.

In the UHU, the majority of older adults were female (68.0\%), married or widowed (42.0\% for both), with hypertension $(51.0 \%)$, non-smokers (96.0\%), that practiced physical activity $(60.0 \%)$, without depressive symptoms (64.0\%) and without cognitive decline (52.0\%). 
Table 1. Distribution of the older adults in the three care modes according to gender, marital status, health profile, mood and cognition. São Carlos - SP, 2014.

\begin{tabular}{|c|c|c|c|c|c|c|c|}
\hline \multirow{2}{*}{ Variables } & \multirow{2}{*}{ Categories } & \multicolumn{2}{|c|}{ LSIOA } & \multicolumn{2}{|c|}{ UH } & \multicolumn{2}{|c|}{ UHU } \\
\hline & & $\mathrm{n}$ & (\%) & $\mathrm{n}$ & (\%) & $n$ & (\%) \\
\hline \multirow{2}{*}{ Gender } & Female & 17 & 45.9 & 26 & 49.9 & 34 & 68.0 \\
\hline & Male & 20 & 54.1 & 27 & 50.1 & 16 & 32.0 \\
\hline \multirow{4}{*}{ Marital status } & Single & 25 & 67.6 & 04 & 7.5 & 04 & 8.0 \\
\hline & Married & 02 & 5.4 & 30 & 56.6 & 21 & 42.0 \\
\hline & Widowed & 09 & 24.3 & 14 & 26.4 & 21 & 42.0 \\
\hline & Separated & 01 & 2.7 & 05 & 9.4 & 04 & 8.0 \\
\hline \multirow{2}{*}{ Diseases } & SAH & 12 & 32.4 & 22 & 41.5 & 25 & 51.0 \\
\hline & DM & 07 & 18.9 & 14 & 26.4 & 12 & 24.5 \\
\hline \multirow{2}{*}{ Smoking } & Yes & 06 & 16.2 & 12 & 22.6 & 02 & 4.0 \\
\hline & No & 31 & 83.8 & 41 & 77.4 & 48 & 96.0 \\
\hline \multirow{2}{*}{ Physical activity } & Yes & 05 & 13.5 & 20 & 37.7 & 30 & 60.0 \\
\hline & No & 32 & 86.5 & 33 & 62.3 & 20 & 40.0 \\
\hline \multirow{2}{*}{ Depressive symptoms } & Yes & 11 & 29.7 & 22 & 41.5 & 18 & 36.0 \\
\hline & No & 26 & 70.3 & 31 & 58.5 & 32 & 64.0 \\
\hline \multirow{2}{*}{ Cognitive decline } & Yes & 37 & 100.0 & 33 & 62.3 & 24 & 48.0 \\
\hline & No & 00 & 0.0 & 20 & 37.7 & 26 & 52.0 \\
\hline Total & & 37 & 100.0 & 53 & 100.0 & 50 & 100.0 \\
\hline
\end{tabular}

SAH: Systemic Arterial Hypertension; DM: Diabetes Mellitus.

Table 2 shows the means, standard deviations and minimum and maximum values for the variables age, schooling, CDT, gross values of the MMSE, Index of Independence in Activities of Daily Living (BADLs), the Instrumental Activities of Daily Living Scale (IADLs) and GDS of the older adults in the different care modalities.

The older adults of the LSIOA presented a mean of 74.4 years of age $(s d=9.8), 1.2$ years of schooling $(s d=1.7), 1.6$ points in the CDT $(s d=1.7), 6.6$ points in the MMSE $(s d=7.7)$, 10.0 points in the IADLs instrument ( $s d=4.1), 2.4$ in the BADLs $(s d=2.2)$ and 4.5 points in the GDS $(s d=3.5)$. The older adults of the $\mathrm{UH}$ presented a mean of 70.8 years of age $(s d=8.1), 4.3$ years of schooling $(s d=3.3), 4.9$ points in the CDT $(s d=2.1)$, 17.3 points in the MMSE $(s d=9.8), 16.1$ points in the IADLs instrument $(s d=5.8), 4.4$ in the BADLs $(s d=2.4)$ and 4.8 points in the GDS $(s d=3.8)$. The older adults of the UHU presented a mean of 75.1 years of age $(s d=9.2), 5.3$ years of schooling ( $s d$ $=5.1), 5.1$ points in the CDT ( $s d=2.4), 19.0$ points in the MMSE $(s d=10.6), 16.1$ points in the IADLs instrument $(s d=6.0), 4.5$ in the BADLs $(s d=2.3)$ and 4.1 points in the GDS $(s d=3.1)$.

Table 3 presents the three care profiles and the main differences related to the item "to have or not cognitive decline".

There was an association between the place of residence of the older adults and the proportion or prevalence of cognitive decline, with $100.0 \%$ in the LSIOA, $62.3 \%$ in the UH and $48.0 \%$ in the UHU $\left(X^{2}=26.29, p<0.001\right)$.

Table 4 shows the multiple logistic regression analysis, having cognitive decline as the outcome and the institution as the preferential predictor, adjusting for gender, age, presence of depressive symptoms and number of morbidities.

Only age was considered a predictor of cognitive decline. Adjusting for the other variables, the chances of prevalence of cognitive decline increase $8.7 \%$ for each additional year of life. The chances of prevalence for the LSIOA could not be calculated as all the older adults presented cognitive decline. This variable was also not statistically significant, indicating that there were no differences between the institutions studied when adjusted for gender, age, depression and number of morbidities.

Table 5 presents the differences in having functional capacity in the three care modes for the older adults.

The overall or omnibus test indicated that there was a statistically significant difference between the mean scores of the two scales among the three institutions $(p<0.001)$. To determine between which institutions the differences were statistically significant, a multiple comparison analysis, using Mann-Whitney for the pairs, was performed. For this, aCP = $a / 3=0.017$ was considered to adjust the multiple comparisons by Bonferroni, revealing statistically significant differences in 
Table 2. Distribution of the older adults in the different care modalities according to the variables age, schooling, CDT, cognitive decline, IADLs, BADLs and GDS. São Carlos - SP, 2014.

\begin{tabular}{lccccccccc}
\hline Variables & $\mathbf{M}(\mathbf{s d})$ & $\begin{array}{c}\text { LSIOA } \\
\text { Min }\end{array}$ & Max & $\mathbf{M}(\mathbf{s d})$ & $\mathbf{M i n}$ & Max & M (sd) & Min & Max \\
\hline Age & $74.4(9.8)$ & 60 & 95 & $70.8(8.1)$ & 60 & 86 & $75.1(9.2)$ & 61 & 96 \\
Schooling & $1.2(1.7)$ & 00 & 04 & $4.3(3.3)$ & 00 & 14 & $5.3(5.1)$ & 00 & 20 \\
CDT & $1.6(1.7)$ & 01 & 09 & $4.9(2.1)$ & 00 & 10 & $5.1(2.4)$ & 01 & 10 \\
\hline MMSE & $6.6(7.7)$ & 00 & 22 & $17.3(9.8)$ & 00 & 30 & $19.0(10.6)$ & 00 & 30 \\
IADLs & $10.0(4.1)$ & 07 & 19 & $16.1(5.8)$ & 07 & 21 & $16.1(6.0)$ & 07 & 21 \\
BADLs & $2.4(2.2)$ & 00 & 06 & $4.4(2.4)$ & 00 & 06 & $4.5(2.3)$ & 00 & 06 \\
GDS & $4.5(3.5)$ & 00 & 11 & $4.8(3.8)$ & 00 & 15 & $4.1(3.1)$ & 00 & 11
\end{tabular}

M: mean; sd: standard deviation; Min: minimum value; Max: maximum value; CDT: Clock Drawing Test; MMSE: Mini Mental State Examination; IADLs: Instrumental Activities of Daily Living; BADLs: Basic Activities of Daily Living; GDS: Geriatric Depression Scale.

Table 3. Distribution of the older adults in relation to the presence of cognitive decline, according to the three care modes (LSIOA, UH and UHU). São Carlos - SP, 2014.

\begin{tabular}{lccccccc}
\hline Presence of cognitive decline & \multicolumn{2}{c}{ Yes } & \multicolumn{2}{c}{ No } & \multicolumn{2}{c}{ Total } \\
& $\mathbf{n}$ & $\mathbf{( \% )}$ & $\mathbf{n}$ & $\mathbf{( \% )}$ & $\mathbf{n}$ & (\%) \\
\hline LSIOA & 37 & 100.0 & 00 & 00.0 & 37 & 26.4 \\
UH & 33 & 62.3 & 20 & 37.7 & 53 & 37.9 \\
UHU & 24 & 48.0 & 26 & 52.0 & 50 & 35.7 \\
\hline Total & 94 & 67.1 & 46 & 32.9 & 140 & 100.0 \\
\hline
\end{tabular}

* Pearson's $\chi^{2}=26.983, p<0.001$.

Table 4. Multiple logistic regression analysis having cognitive decline as the outcome. São Carlos - SP, 2014.

\begin{tabular}{|c|c|c|c|c|}
\hline \multirow{2}{*}{ Variables } & \multirow{2}{*}{$p$-value } & \multirow{2}{*}{ OR } & \multicolumn{2}{|c|}{$95 \% \mathrm{Cl}$} \\
\hline & & & LL & UL \\
\hline Institution & 0.161 & 2.430 & 0.978 & 6.039 \\
\hline Gender & 0.579 & 0.777 & 0.319 & 1.895 \\
\hline Age & $0.002^{*}$ & 1.087 & 1.030 & 1.147 \\
\hline $\begin{array}{l}\text { Depressive } \\
\text { symptoms }\end{array}$ & 0.325 & 1.602 & 0.626 & 4.102 \\
\hline Morbidities & 0.169 & 0.732 & 0.469 & 1.142 \\
\hline
\end{tabular}

functional capacity, both for the BADLs and IADLs, between the LSIOA and UH $(p<0.001)$ and the LSIOA and UHU $(p<$ 0.001). Regarding the performance in the BADLs and IADLs, the older adults of the LSIOA were more dependent. There was no statistically significant difference between the $\mathrm{UH}$ and $\mathrm{UHU}$.

\section{DISCUSSION}

In the present study, the participants presented low levels of schooling in all care models. During the childhood of these older adults, education was not seen as a priority, reflecting today in older adults with low levels of education. ${ }^{16}$ Faced with this, health professionals should evaluate the interpretation and understanding of actions directed toward health education, taking into consideration that low levels of schooling may hinder the understanding of guidelines. ${ }^{17}$

Older adults with lower levels of education have little or no knowledge of the need for access to the services for health promotion actions and are less likely to seek continuity of care for the prevention of illness and complications, and at the same time more often choose a emergency service. ${ }^{18}$ Authors highlight that low levels of schooling are strongly related to the cognitive impairment and functional incapacity of older adults. ${ }^{6,19}$

Among the institutionalized participants, there was a predominance of dependence in the basic and instrumental activities of daily living. Similar data were found in a study conducted in Marilia (SP), with the aim of studying depressive symptoms and cognitive and functional decline in older adults residing in an LSIOA. The authors found that the performance of activities of daily living in the institutional context becomes impaired, considering the limitations that the environment itself imposes in relation to the social functions. Furthermore, situations that involve decision making are practically non-existent, considering the organization, rules and routine of the LSIOAs. ${ }^{6}$ Conversely, the finding of high dependence in older adults can highlight the risk factor for institutionalization.$^{20}$ The demand for institutionalization has increased in recent years, reflecting the 
Table 5. Distribution of the means, medians and p-value in the three care modalities, related to the performance of the older adults in BADLs and IADLs. São Carlos - SP, 2014.

\begin{tabular}{lcccccc}
\hline Care Modes & Mean & $\begin{array}{c}\text { BADLs } \\
\text { Median }\end{array}$ & $\boldsymbol{p}$-value* & Mean & $\begin{array}{c}\text { IADLs } \\
\text { Median }\end{array}$ & $\boldsymbol{p}$-value* \\
\hline LSIOA & 2.35 & 2.00 & & 9.97 & 7.00 & \\
UH & 4.42 & 6.00 & $<0.001$ & 16.15 & 19.00 & $<0.001$ \\
UHU & 4.54 & 6.00 & & 16.10 & 20.00 & \\
\hline
\end{tabular}

* Kruskal-Wallis.

changes in family and social dynamics, accompanied by the difficulty for family members to find people capable of being responsible for the care of the older adult. ${ }^{21}$ In this context, the demand increases for LSIOAs that provide the care necessary for dependent older adults, overcoming the lack of family and social support.

Regarding outpatient and inpatient settings, the majority of the older adults were independent for BADLs and IADLs. These data were partially corroborated by the literature. A crosssectional study carried out at the Geriatric Outpatient Clinic of the Clinical Hospital of UNICAMP analyzed the profile of the older adults regarding mood and loss of functional and cognitive capacity. The authors found that the majority of the participants reported independence for BADLs (63\%) and dependence for IADLs (68.3\%). ${ }^{22}$

A study carried out with 94 older adult patients admitted to a university hospital in Belém indicated that there was some degree of dependency in the BADLs $(61.7 \%)$ and in the IADLs $(52.1 \%)$. The authors stated that hospitalization is a known risk factor for the functional decline of older adults, who lose their autonomy in this context. In addition, an already existing functional impairment may be potentiated, due to excessive time in bed, sleep deprivation and the use of multiple medications. ${ }^{23}$

The literature shows a hierarchy of functional capacity loss in older adults, when thinking about care models for the older adult. In the outpatient model, the older adults are more independent when compared to those in the hospital and institution contexts. A gradual increase in the severity of functional dependence is observed when hospital services are sought, which culminates in severe dependence in those who seek or even reside in longstay institutions.

The study of functional capacity provides subsidies for the planning and systematization of the care provided by the health professional, in relation to older adults. Strategies developed in the context of a multidisciplinary team aiming to assist or restore their functional capacity may be necessary. In addition, emphasis can be given to maintaining/strengthening activities in which the older adults do not present difficulties. ${ }^{17}$

The evaluation of the mental state in this study showed that $100 \%$ of the older adults of the LSIOA presented cognitive alterations, with a low mean in the MMSE (6.6 points). A study carried out in Belo Horizonte - MG with 47 institutionalized older adults revealed that the cognitive decline was highly prevalent in the older adults of LSIOAs, with $93.3 \%$ presenting cognitive impairment. ${ }^{21}$

The evaluation of the cognitive performance of the older adults in the hospital showed that $62.3 \%$ presented cognitive decline, with an mean of 17.3 points. These data are in agreement with the literature. Hospitalized older adult patients presented a mean of 18.14 points in the MMSE, in a study conducted in Belém. ${ }^{23}$

Of the older adult outpatients, $48 \%$ presented cognitive decline, obtaining a mean score of 19 points in the MMSE. Other national studies found that cognitive deficits were present in $29 \%$ of the older adults evaluated. ${ }^{22,24}$

Researchers have indicated that institutionalized older adults present lower cognitive performance and less functional activity when compared to non-institutionalized older adults. ${ }^{25}$

The results of this study demonstrated that the different health service modalities have a strong influence on the cognitive performance of older adults. Incapacitating chronic diseases, such as dementia, are a major risk factor for institutionalization, therefore it is common to have many older adults with cognitive decline in these institutions. However, social isolation, withdrawal of the older adult from the community, the sedentary lifestyle imposed by the LSIOA and the lack of intellectual stimulation in this context can be important factors for the development and/or aggravation of cognitive changes. ${ }^{26,27}$ Cognitive repercussions over time should be monitored from the first day of institutionalization.

Age was considered a predictive factor for cognitive alterations. Organic changes occur throughout the aging process, which can result in a reduced ability to maintain homeostasis and in health complications that compromise different areas, such as a progressive decline in cognitive functions. ${ }^{28}$ Memory losses are the most frequent complaints among older adults. ${ }^{29}$ With the advance of age, there is a greater predisposition to chronic diseases and, in senility, impairments occur with greater intensity, and there may be changes in the nervous system, culminating in cognitive deficits and, often, in the impairment of the performance of activities of daily living. ${ }^{26}$

These data demonstrate that it is necessary to apply screening instruments for cognitive function as soon as the patients are admitted to the different models of healthcare for the older adult. This evaluation, as part of the health services routine, will provide subsidies for health professionals to work in the preventive and rehabilitation programs in a more effective way. ${ }^{23}$ 
In the evaluation of mood, $29.7 \%$ of the institutionalized older adults, $41.5 \%$ of those hospitalized and $36 \%$ of those in the clinic presented depressive symptoms. A national study found that $32 \%$ of the participants presented depressive symptoms, being more prevalent among those that were younger, female, less educated and had lower scores in the MMSE. ${ }^{22}$ Depression is not directly related to aging, however, the onset of aging presents some atypical characteristics or particularities that predispose the person to the development of depressive symptoms, such as retirement and the reduction of the possibility of fulfilling a productive role, which generally leads to demoralization and loss of status. ${ }^{30}$

Although the older adults with depressive symptoms were in the minority in the different services, special attention should be paid to these individuals. Strategies such as leisure, social and cultural activities can be carried out by the multidisciplinary team.

The following limitations were verified in the present study: 1) the transversal sample did not allow causality to be attributed among the variables; 2 ) the lack of studies comparing the three care modalities for older adults, outpatient, hospital and long-stay, hampered the discussion of some findings; 3 ) the use of questionnaires may have underestimated or overestimated some information found; 4) the various research instruments and parameters used to classify the functional capacity of the older adults, as well as the cut-off point, make it difficult to compare the results with the other studies.

Further longitudinal studies that consider the relationship between functional capacity, cognition and depressive symptoms for older adults in different care contexts are suggested, considering the lack of these in the literature.

\section{CONCLUSION}

The presence of debilitated and totally dependent older adults, with severe cognitive impairments was more prevalent in the LSIOA context. The hospital and the outpatient clinic were similar in terms of the functional capacity of the older adults, however, in the hospital the older adults presented greater cognitive impairment and a higher prevalence of depressive symptoms, this being in agreement with the profile and complexity of each older adult care model.

The likelihood of prevalence of cognitive decline increased with age when related to the hospital and outpatient mode, which reveals the association between the place of residence of the older adult and the prevalence of cognitive decline.

Considering the above, it is important to compare the three care models for older adults, since the planning of the actions is carried out in an appropriate, real and particular way for each scenario, providing the health team with the capacity to tailor the interventions to the older adults involved.

\section{ACKNOWLEDGMENTS}

The authors thank the National Council for Scientific and Technological Development (CNPq) for the financial support, CNPq Universal Request for Proposals 2012-2015, PROCESS 484864/2012-2.

\section{REFERENCES}

1. Thun MJ, DeLancey JO, Center MM, Jemal A, Ward EM. The global burden of cancer: priorities for prevention. Carcinogenesis [Internet] 2010 Jan; [cited 2017 Jan 2]; 31(1):100-10. Available from: https:// www.ncbi.nlm.nih.gov/pmc/articles/PMC2802672/pdf/bgp263.pdf. DOI: 10.1093/carcin/bgp263

2. Mendes ACG, Sá DA, Miranda GMD, Lyra TM, Tavares RAW Assistência pública de saúde no contexto da transição demográfica brasileira: exigências atuais e futuras. Cad Saúde Pública [Internet]. 2012 May; [cited 2016 Dec 28]; 28(5):955-64. Available from: http:// www.scielo.br/pdf/csp/v28n5/14.pdf. http://dx.doi.org/10.1590/S0102$311 \times 2012000500014$

3. Mendes EV. O cuidado das condições crônicas na atenção primária à saúde: o imperativo da consolidação da Estratégia Saúde da Família. 1a ed. Brasília: Organização Pan-Americana de Saúde; 2012. Available from: http://www.saude.go.gov.br/public/media/1IUN5gHxOAAG Wd/18446212121840542550.pdf

4. Tomomitsu MRS, Perracini MR, Neri AL. Fatores associados à satisfação com a vida em idosos cuidadores e não cuidadores. Ciênc Saúde Coletiva [Internet]. 2014 Aug; [cited 2016 Oct 31]; 19(8):342940. Available from: http://www.scielo.br/scielo.php?script=sci arttext\&pid=S1413-81232014000803429\&Ing=en\&nrm=iso. http:// dx.doi. org/10.1590/1413-81232014198.13952013

5. Gratão ACM, Talmelli LFS, Figueiredo LC, Rosset I, Freitas CP, Rodrigues RAP. Functional dependency of older individuals and caregiver burden. Rev Esc Enferm USP [Internet]. 2013 Feb; [cited 2016 Nov 1]; 47(1):137-44. Available from: http://www.scielo.br/scielo. php?script=sci_arttext\&pid=S0080-62342013000100017.http://dx.doi. org/10.1590/S0080-62342013000100017

6. Soares E, Coelho MO, Carvalho SMR. Capacidade funcional, declínio cognitivo e depressão em idosos institucionalizados: possibilidade de relações e correlações. Rev Kairós Gerontol [Internet]. 2012 Sep; [cited 2017 Feb 22]; 15(5):117-39. Available from: http://revistas.pucsp.br/ index.php/kairos/article/view/9541/11434

7. Brucki SMD, Nitrini R, Caramelli P, Bertolucci PHF, Okamoto IH. Sugestões para o uso do mini-exame do estado mental no Brasil. Arq Neuropsiquiatr [Internet]. 2003; [cited 2016 Dec 28]; 61(3-B):777-81. Available from: http://www.scielo.br/pdf/anp/v61n3B/17294.pdf

8. Alcântara AO, Camarano AA, Giacomin AC, orgs. Política nacional do idoso: velhas e novas questões. Rio de Janeiro: IPEA; 2016 [cited 2017 Feb 22]. Available from: http://www.ipea.gov.br/portal/images/stories/ PDFs/livros/livros/161006_livro_politica_nacional_idosos.PDF

9. Organização Mundial da Saúde. Relatório Mundial de Envelhecimento e Saúde. Genebra: Organização Mundial da Saúde;2015.30 p. [cited 2017 Jul 21]. Available from: http://sbgg.org.br/wp-content/uploads/2015/10/ OMS-ENVELHECIMENTO-2015-port.pdf

10. Bertolucci PHF, Brucki SMD, Campacci SR, Juliano Y. O mini-exame do estado mental em uma população geral: impacto da escolaridade. Arq Neuropsiquiatr. [Internet]. 1994; [cited 2016 Dec 28]; 52(1):1-7. Available from: http://www.scielo.br/pdf/anp/v52n1/01.pdf

11. Atalaia-Silva KS, Lourenço RA. Translation, adaptation and construct validation of the Clock Test among elderly in Brazil. Rev Saúde Pública [Internet]. 2008; [cited 2016 Dec 28]; 42(5):930-7. Available from: http:// www.scielo.br/pdf/rsp/v42n5/en_5765.pdf. http://dx.doi.org/10.1590/ S0034-89102008000500020

12. Almeida OP, Almeida AS. Confiabilidade da versão brasileira da escala de depressão em geriatria (GDS) versão reduzida. Arq Neuropsiquiatr [Internet]. 1999 Jun; [cited 2016 Dec 28];57(2-B):421-6. Available from: http://www.scielo.br/pdf/anp/v57n2B/1446.pdf. http://dx.doi. org/10.1590/S0004-282X1999000300013

13. Lino VTS, Pereira SRM, Camacho LAB, Ribeiro Filho ST, Buksman S. Adaptação transcultural da Escala de Independência em Atividades da Vida Diária (Escala de Katz). Cad Saúde Pública [Internet]. 2008 Jan; [cited 2017 Jan]; 24(1):103-12. Available from: http://www. scielo.br/pdf/csp/v24n1/09.pdf. http://dx.doi.org/10.1590/S0102311 X2008000100010 
14. Shelkey M, Wallace M. Katz Index of Independence in Activities of Daily Living (ADL). Slightly adapted from Katz S, Down TD, Cash HR, Grotz RC. Progress in the development of the index of ADL. The Gerontologist. [Internet]. 2012; [cited 2017 Jan 2]; 10(1):20-30. Available from: https:// consultgeri.org/try-this/general-assessment/issue-2.pdf

15. Santos RL, Virtuoso Júnior JS. Confiabilidade da versão brasileira da escala de atividades instrumentais da vida diária. Rev Bras Promoç Saúde [Internet]. 2008 Oct/Dec; [cited 2017 Jan 2]; 21(4):290-6. Available from: https://www.researchgate.net/publication/26609262_ Reliability_of_the_Brazilian_version_of_the_Scale_of_Instrumental_ Activities_of_Daily_Living

16. Sthal HC, Berti HW, Palhares VC. Caracterização de idosos internados em enfermaria de pronto socorro quanto a vulnerabilidade social e programática. Esc Anna Nery [Internet]. 2010 Oct/Dec; [cited 2017 Jan 2]; 14(4):697-701. Available from: http://www.scielo.br/pdf/ean/v14n4/ v14n4a07.pdf. http://dx.doi.org/10.1590/S1414-81452010000400007

17. Nunes WA, Dias FA, Nascimento JS, Gomes NC, Tavares DMS. Cognição, funcionalidade e indicativo de depressão entre idosos. Rev Rene [Internet]. $2016 \mathrm{Jan} / F e b ;$ [cited 2017 Feb 22]; 17(1):103-11. Available from: http://www.periodicos.ufc.br/index.php/rene/article/ view/2621/2008. DOI: 10.15253/2175-6783.2016000100014

18. Louvison MC, Lebrão ML, Duarte YAO, Santos JLF, Malik AM, Almeida ES. Desigualdades no uso e acesso aos serviços de saúde entre idosos do município de São Paulo. Rev Saúde Pública [Internet]. 2008 Aug; [cited 2017 Jan 2]; 42(4):733-40. Available from: http://www. scielo.br/pdf/rsp/v42n4/6846.pdf. http://dx.doi.org/10.1590/S003489102008000400021

19. Lima CLJ, Costa MML, Ferreira JDL, Silva MA, Ribeiro JKS, Soares MJGO. Sociodemographic and clinical profile of institutionalized elderly people. Rev Enferm UFPE On Line [Internet]. 2013 Oct; [cited 2017 Feb 22]; 7(10):6027-34. Available from: http://www.revista.ufpe.br/ revistaenfermagem/index.php/revista/article/viewFile/4710/pdf_3670. DOI: 10.5205/reuol.4377-36619-1-ED.0710201325

20. Lini EV, Doring M, Machado VLM, Portella MR. Idosos institucionalizados: prevalência de demências, características demográficas, clínicas e motivos da institucionalização. Rev Bras Ciênc Envelhec Hum [Internet]. 2014 Sep/Dec; [cited 2017 Feb 22]; 11(3):267-75. Available from: http://seer.upf.br/index.php/rbceh/article/view/4482/pdf. http://dx.doi. org/10.5335/rbceh.2014.4482

21. Alencar MA, Bruck NNS, Pereira BC, Câmara TMM, Almeida RDS. Perfil dos idosos residentes em uma instituição de longa permanência. Rev Bras Geriatr Gerontol [Internet]. 2012 Oct/Dec; [cited 2017 Jan 2]; 15(4):785-96. Available from: http://www.scielo.br/scielo. php?script=sci arttext\&pid=S1809-98232012000400017\&lng=pt http://dx.doi.org/10.1590/S1809-98232012000400017

22. Paula AFN, Ribeiro LHM, D'Elboux MJ, Guariento MH. Assessing the functional, cognitive capacity, and depressive symptoms in elderly patients from geriatric service. Rev Bras Clin Med [Internet]. $2013 \mathrm{Jul} /$ Sep; [cited 2017 Jan 2]; 11(3):212-8. Available from: http://files.bvs.br/ upload/S/1679-1010/2013/v11n3/a3767.pdf

23. Pereira EEB, Souza ABF, Carneiro SR, Sarges ESNF. Funcionalidade global de idosos hospitalizados. Rev Bras Geriatr Gerontol [Internet] 2014 Mar; [cited 2017 Feb 22]; 17(1):165-76. Available from: http:// www.scielo.br/pdf/rbgg/v17n1/1809-9823-rbgg-17-01-00165.pdf. DOI: 10.1590/S1809-98232014000100016

24. Gratão ACM, Fonseca GPS, Parreira CO, Faustino AM, Cruz KCT. Proposta de protocolo de assistência de enfermagem ao idoso demenciado. Rev Enferm UFPE On Line. [Internet] 2014 Apr; [cited 2017 Jan 2]; 8(4):879-88. Available from: http://www.revista.ufpe.br/ revistaenfermagem/index.php/revista/article/download/4079/pdf_4866. DOI: 10.5205/reuol.5829-50065-1-ED-1.0804201412

25. Trindade APNT, Barboza MA, Oliveira FB, Borges APL. Repercussão do declínio cognitivo na capacidade funcional em idosos institucionalizados e não institucionalizados. Fisioter Mov [Internet]. 2013 Apr/Jun; [cited 2017 Feb 22]; 26(2):281-9. Available from: http://www.scielo.br/ pdf/fm/v26n2/05.pdf

26. Zimmermann IMM, Leal MCC, Zimmermann RD, Marques APO, Gomes ECC. Factors associated with cognitive impairment in institutionalized elderly individuals: integrative review. J Nurs UFPE On line [Internet]. 2015 Dec; [cited 2017 Feb 22]; 9(12):1320-8. Available from: http://www. revista.ufpe.br/revistaenfermagem/index.php/revista/article/view/8818/ pdf_9129. DOI: 10.5205/reuol.8127-71183-1-SM.0912201534

27. Castro SD, Prudente COM. Perfil sócio-demográfico, mental e funcional de idosos institucionalizados da cidade de Caldas Novas. Rev Eletr Saúde Ciênc [Internet]. 2012; [cited 2017 Jan 2]; 2(1):78-102. Available from: http://www.rescceafi.com.br/vol2/n1/Artigo-Vl-78-102.pdf

28. Jockwitz C, Caspers S, Lux S, Eickhoff SB, Jütten K, Lenzen S, et al. Influence of age and cognitive performance on resting-state brain networks of older adults in a population-based cohort. Cortex [Internet] 2017 Apr; [cited 2017 Feb 23]; 89:28-44. Available from: http://www. sciencedirect.com/science/article/pii/S0010945217300126. http:// dx.doi.org/10.1016/j.cortex.2017.01.008

29. Ferreira LS, Pinho MSP, Pereira MWM, Ferreira AP. Perfil cognitivo de idosos residentes em instituições de longa permanência de Brasília - DF. Rev Bras Enferm [Internet]. 2014 Mar/Apr; [cited 2017 Feb 22]; 67(2):247-51. Available from: http://www.scielo.br/pdf/ reben/v67n2/0034-7167-reben-67-02-0247.pdf. DOI 10.5935/00347167.20140033

30. Suassuna PD, Veras RP, Lourenço RA, Caldas CP. Fatores associados a sintomas depressivos em idosos atendidos em ambulatório público de Geriatria. Rev Bras Geriatr Gerontol [Internet]. 2012 Oct/Dec; [cited 2017 Jan 2]; 15(4):643-50. Available from: http://www.scielo.br/pdf/rbgg/ v15n4/05.pdf. http://dx.doi.org/10.1590/S1809-98232012000400005

\footnotetext{
a Article derived from the Master's Dissertation entitled "Cognitive and Functional Assessment of Elderly Users from the Public Health Service and Caregivers Burden", presented to the Graduate Program in Nursing of the Federal University of São Carlos (PPGEnf-UFSCar), 2015. The Dissertation is part of the Research Project "Integral Healthcare for Older Adults and Caregivers in the Municipality of São Carlos", financed through the CNPq Universal Request for Proposals 2012-2015, PROCESS 484864/2012-2.
} 